Biological Integrity of Streams in the Ruby River TMDL Planning Area Based on the Structure and Composition of the Benthic Algae

Community

Bahls, Loren

2003 
MONTANA STATE LIBRARY $\left.\right|_{30864} ^{||} 00105810$ 


\section{BIOLOGICAL INTEGRITY OF STREAMS IN THE RUBY RIVER TMDL PLANNING AREA BASED ON THE STRUCTURE AND COMPOSITION OF THE BENTHIC ALGAE COMMUNITY}

Prepared for:

State of Montana

Department of Environmental Quality

P.O. Box 200901

Helena, Montana 59620-0901

Project Officer: Alan Nixon

DEQ Contract No. 200012-8

\section{Prepared by:}

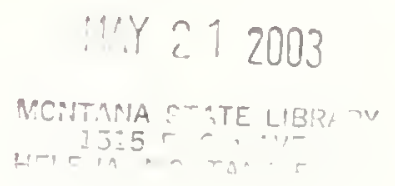

Loren L. Bahls, Ph.D.

\section{Hannaea}

1032 Twelfth Avenue

Helena, Montana 59601

April 9, 2003 


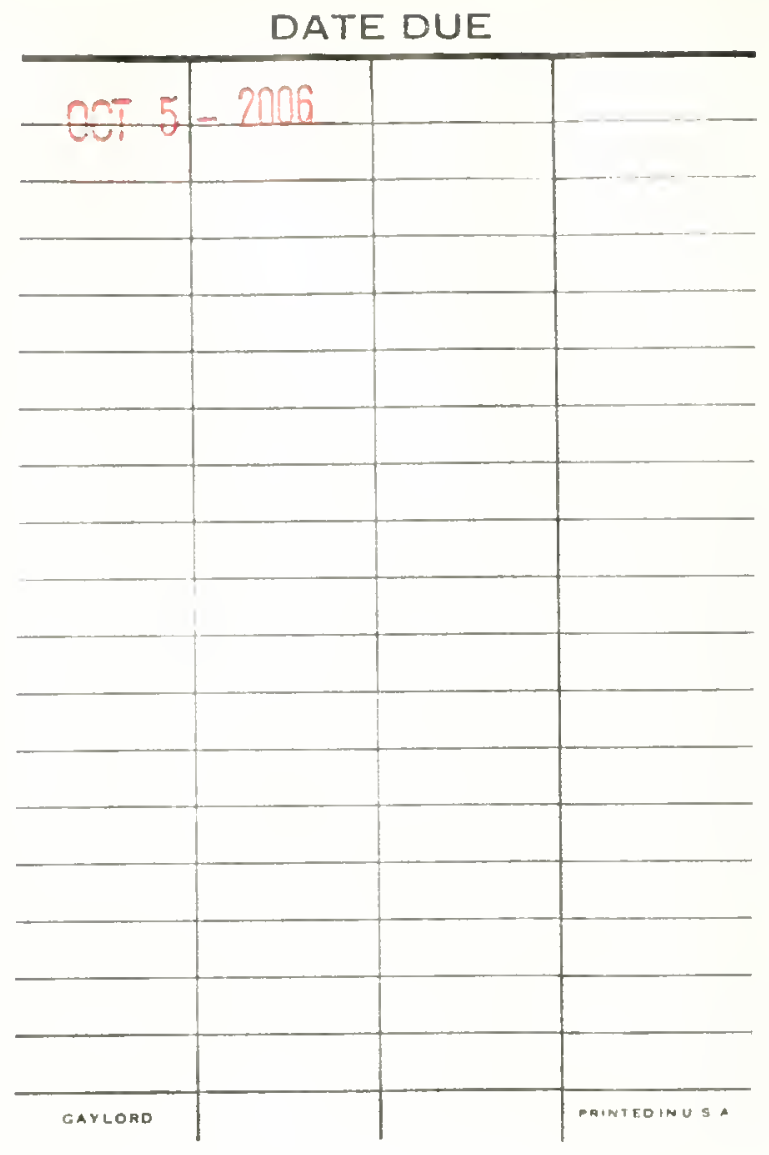




\section{Summary}

In July and September 2002, periphyton samples were collected from 20 sites on 14 streams in the Ruby River TMDL planning area in southwestern Montana for the purpose of assessing whether these streams are water-quality limited and in need of TMDLs. The samples were collected following MDEQ standard operating procedures, processed and analyzed using standard methods for periphyton, and evaluated following modified USEPA rapid bioassessment protocols for wadeable streams.

At the lower site on Coal Creek, a depressed pollution index and an elevated siltation index indicated minor impairment from organic loading and sedimentation. Other than slight organic loading at the upper site on Indian Creek, diatom metrics indicated excellent biological integrity, no impairment, and full support of aquatic life uses at both sites on this stream. An elevated siltation index and a depressed pollution index indicate moderate impairment from sedimentation and minor impairment from organic loading in lower Ramshorn Creek.

In addition to the natural stress evident in Currant Creek, this site exhibited minor impairment from sedimentation. Other metrics indicated no impairment and excellent biological integrity. The lower site on California Creek supported an exceptionally large number of motile diatoms for a mountain stream, which indicated severe impaimen from sedimentation. A slightly depressed pollution index suggests minor impairment from organic loading at this site. Borderline values for the pollution index and siltation index suggest minor impairment from organic loading and sedimentation in Harris Creek.

Aside from a large number of Achnanthidium minutissimum and natural stress due to steep gradients, coldwater temperatures and low nutrients, diatom metrics indicate good biological integrity in Shovel Creek. Hawkeye Creek supported an exceptionally large number of motile diatoms for a mountain stream, suggesting severe impairment from sedimentation. This site also had a slightly depressed pollution index, indicating minor impairment from organic loading. An elevated number of motile diatoms indicate minor impairment from sedimentation in Warm Springs Creek. One teratological diatom valve was counted at this site. Otherwise, diatom metrics indicated excellent biological integrity.

Mill Gulch had excellent biological integrity for a mountain stream and diatom species richness was exceptional (70 species counted). The lower site on Garden Creek supported an elevated number of motile diatoms, indicating minor impairment from sedimentation. An elevated number of motile diatoms in Mormon Creek indicate moderate impairment from sedimentation. A depressed pollution index also indicates minor impairment from organic loading. A relatively large number of teratological diatoms suggest that this site may have elevated concentrations of heavy metals.

More than 13 percent of the diatoms in the North Fork of Greenhorn Creek were abnormal, which suggests severe impairment from heavy metals. The number of motile diatoms here was also elevated, indicating minor impairment from sedimentation. A large number of motile diatoms indicate moderate impaiment from sedimentation in the West Fork of the Ruby River. The pollution index was also depressed here, indicating minor impairment from organic loading. 


\section{Introduction}

This report evaluates the biological integrity ${ }^{1}$, support of aquatic life uses, and probable causes of stress or impaiment to aquatic communities in selected streams of the Ruby River TMDL planning area in southwestern Montana. The purpose of this report is to provide information that will help the State of Montana determine whether these streams are waterquality limited and in need of TMDLs.

The federal Clean Water Act directs states to develop water pollution control plans (Total Maximum Daily Loads or TMDLs) that set limits on pollution loading to water-quality limited waters. Water-quality limited waters are lakes and stream segments that do not meet waterquality standards, that is, that do not fully support their beneficial uses. The Clean Water Act and USEPA regulations require each state to (1) identify waters that are water-quality limited, (2) prioritize and target waters for TMDLs, and (3) develop TMDL plans to attain and maintain water-quality standards for all water-quality limited waters.

Evaluation of aquatic life use support in this report is based on the species composition and structure of periphyton (benthic algae, phytobenthos) communities at 20 sites on 14 streams that were sampled in July and September of 2002. Periphyton is a diverse assortment of simple photosynthetic organisms called algae that live attached to or in close proximity of the stream bottom. Some algae form long filaments or large colonies and are conspicuous to the unaided eye. But most algae, including the ubiquitous diatoms, can be seen and identified only with the aid of a microscope. The periphyton community is a basic biological component of all aquatic ecosystems. Periphyton accounts for much of the primary production and biological diversity in Montana streams (Bahls et al. 1992). Plafkin et al. (1989) and Barbour et al. (1999) list several advantages of using periphyton in biological assessments.

\footnotetext{
${ }^{1}$ Biological infegrity is defined as "the ability of an aquatic ecosystem to support and maintain a balanced, integrated, adaptive community of organisms having a species composition, diversily, and functional organization comparable to that of natural habitals within a region" (Karr and Dudley 1981).
} 


\section{Project Area and Sampling Sites}

The project area is located within the Middle Rockies Ecoregion (USEPA 2000) in Madison County, Montana. At higher elevations, vegetation is mainly mixed conifer forest, with alpine tundra on the highest peaks. At lower elevations, vegetation is mainly mixed grassland and sagebrush steppe (USDA 1976, Woods et al. 1999). The main land uses are livestock grazing and irrigated agriculture.

Periphyton samples were collected at 20 sites on 14 streams (Table 1). The study streams are in the Ruby River hydrologic unit (USGS HUC 10020003). The Ruby River, along with the Big Hole and the Beaverhead Rivers, are the three main tributaries of the Jefferson River. Streams in the project area are classified B-1 in the Montana Surface Water Quality Standards.

\section{Methods}

Periphyton samples were collected following standard operating procedures of the MDEQ Planning, Prevention, and Assistance Division. Using appropriate tools, microalgae were scraped, brushed, or sucked from natural substrates in proportion to the importance of those substrates at each study site. Macroalgae were picked by hand in proportion to their abundance at the site. All collections of nicroalgae and macroalgae were pooled into a common container and preserved with Lugol's (IKI) solution.

The samples were examined to estimate the relative abundance and rank by biovolume of diatoms and genera of soft (non-diatom) algae according to the method described in Bahls (1993). Soft algae were identified using Smith (1950), Prescott (1962, 1978), John et al. (2002), and Wehr and Sheath (2003). These books also served as references on the ecology of the soft algae, along with Palmer $(1969,1977)$.

After the identification of soft algae, the raw periphyton samples were cleaned of organic matter using sulfuric acid, potassium dichromate, and hydrogen peroxide. Then permanent diatom slides were prepared using Naphrax, a high refractive index mounting medium, following 
Standard Methods for the Examination of Water and Wastewater (APHA 1998). At least 400 diatom cells ( 800 valves) were counted at random and identified to species. The following were the main taxonomic references for the diatoms: Krammer and Lange-Bertalot 1986, 1988, 1991 a, 1991b; Lange-Bertalot 1993, 2001; Krammer 1997a, 1997b, 2002; Reichardt 1997, 1999. Diatom naming conventions followed those adopted by the Academy of Natural Sciences for USGS NAWQA samples (Morales and Potapova 2000) as updated in 2003 (Dr. Eduardo Morales, Academy of Natural Sciences, digital communication). Van Dam et al. (1994) was the main ecological reference for the diatoms.

The diatom proportional counts were used to generate an array of diatom association metrics. A metric is a characteristic of the biota that changes in some predictable way with increased human influence (Barbour et al. 1999). Diatoms are particularly useful in generating metrics because there is a wealth of information available in the literature regarding the pollution tolerances and water quality preferences of common diatom species (e.g., Lowe 1974, Beaver 1981, Lange-Bertalot 1996, Van Dam et al. 1994).

Values for selected metrics were compared to biocriteria (numeric thresholds) developed for streams in the Rocky Mountain ecoregions of Montana (Table 2). These criteria are based on metric values measured in least-impaired reference streams (Bahls et al. 1992) and metric values measured in streams that are known to be impaired by various sources and causes of pollution (Bahls 1993). The biocriteria in Table 2 are valid only for samples collected during the summer field season (June 21 -September 21).

The criteria in Table 2 distinguish among four levels of stress or impairment and three levels of aquatic life use support: (1) no impairment or only minor impairment (full support); (2) moderate impairment (partial support); and (3) severe impairment (nonsupport). These impairment levels correspond to excellent, good, fair, and poor biological integrity, respectively. In cold, high-gradient mountain streams, natural stressors will often mimic the effects of mancaused impairment on some metric values. 


\section{Quality Assurance}

Several steps were taken to assure that the study results are accurate and reproducible.

Upon receipt of the samples, station and sample attribute data were recorded in the Montana Diatom Database and the samples were assigned a unique number, e.g., 2626-01. The first part of this number (2626) designates the sampling site (Currant Creek) and the second part (01) designates the number of periphyton samples that that have been collected at this site for which data have been entered into the Montana Diatom Database.

Sample observations and analyses of soft (non-diatom) algae were recorded in a lab notebook along with information on the sample label. A portion of the raw sample was used to make duplicate diatom slides. The slide used for the diatom proportional count will be deposited in the Montana Diatom Collection at the University of Montana Herbarium in Missoula. The duplicate slide will be retained by Hannaea in Helena. Diatom proportional counts have been entered into the Montana Diatom Database.

\section{Results and Discussion}

Results are presented in Tables 3, 4 and 5, which are located near the end of this report following the references section. Copies of aquatic plant field sheets are included as Appendix A. Appendix B contains a series of diatom reports, one for each sample. Each diatom report contains an alphabetical list of diatom species in that sample and their percent abundances, and values for 65 different diatom metrics and ecological attributes.

\section{Sample Notes}

Coal Creek. The coarse filamentous green alga found at the upper site was sparsely branched and therefore placed into Rhizoclonium rather than Cladophora. The Cladophora, Oedogonitum, and Tolypothrix found at the lower site on 9/19/02 were senescent. 
Indian Creek. Algae were sparse in the sample from the upper site, which consisted mostly of a few pebbles. The unknown cyanophyte at the lower site was a unicellular coccoid that sometimes formed small colonies.

Ramshorn Creek. The sample from the upper site contained moss. The sample from the lower site was very silty.

Currant Creek. The sample from Currant Creek contained macrophytes.

California Creek. The sample from the lower site was very silty; Cladophora in this sample consisted of one large unbranched filament.

Harris Creek. This sample was silty and contained moss and macrophytes.

Shovel Creek. This sample was silty and partly decomposed (smelled of hydrogen sulfide).

Hawkeye Creek. This sample was very silty and partly decomposed (smelled of hydrogen sulfide). The Cladophora in this sample was senescent.

Warm Springs Creek. This sample contained macrophytes and moss.

Mill Gulch. This sample was mostly moss.

Garden Creek. The samples from both sites were decomposing (smelled of hydrogen sulfide). The sample from the lower site was very silty and contained macrophytes.

Mormon Creek. This sample contained moss, lots of silt, and two large pebbles.

North Fork Greenhorn Creek. Teratological cells of Synedra ulna were common in a scan of the raw sample. The sample contained moss. 
West Fork Ruby River. This sample was very silty an in the process of decomposing (smelled of hydrogen sulfide).

\section{Non-Diatom Algae}

Coal Creek. Coal Creek supported a diverse mixture of diatoms, green and blue-green algae (Table 3). The xanthophyte Tribonema, which indicates cool water of good quality, was also present at the upstream site. The nitrogen-fixing cyanophyte Tolypothrix, another indicator of cool, clean water, was the dominant alga at the upper site. Other nitrogen-fixing cyanophytes (Anabaena, Nostoc, Nodularia, Rivularia) were also common in Coal Creek, indicating that nitrogen may be the limiting nutrient here. Diatoms ranked first in biovolume at the mouth of Coal Creek in July and the filamentous green alga Cladophora ranked first here in September. Coal Creek supported more genera of non-diatom algae than any of the other streams in the study area (Table 3).

Indian Creek. The sample from the upper site on Indian Creek contained only diatoms, which were common. Cladophora was most abundant in the sample from the lower site, which also contained diatoms and three genera of cyanobacteria (Table 3).

Ramshorn Creek. Diatoms were the most abundant algae at both sites on Ramshorn Creek (Table 3). The upper site supported 9 genera of non-diatom algae, including the rare brown alga Heribaudiella and the red alga Audouinella. Both of these genera indicate cool flowing waters of good quality. Diatoms and Cladophora ranked first and second in biomass at the downstream site on Ramshom Creek, followed by Vaucheria, a xanthophyte that indicates a steady supply of water at this site.

Currant Creek. Diatoms were the most common algae in the sample from Currant Creek, followed by three genera of cyanobacteria and the desmid Closterium (Table 3). 
California Creek. Ulothrix, an unbranched filamentous green alga, was most abundant at the upper site, followed by the chrysophyte Hydrums foetidus (Table 3). H. foetidus forms slimy, mucilaginous colonies in clear, cold streams in full sunlight. It is known for the offensive odor that it emits. Diatoms were common and ranked third in biovolume at the upper site. Near the mouth of California Creek, diatoms were abundant and ranked first in biovolume. Ulothrix and Hydrums were absent at the lower site and were replaced by a more conventional algal flora. Here the cyanophyte Osciallatoria and the filamentous green alga Cladophora ranked second and third in biovolume, respectively.

Harris Creek. The most abundant alga here was the xanthophyte Valucheria, which indicates a steady flow of water. Diatoms were frequent and ranked second. Common genera of green and blue-green algae were also found here (Table 3).

Shovel Creek. The filamentous cyanophyte Oscillatoria was the only non-diatom alga found at this site (Table 3). Diatoms were abundant and ranked first in biovolume.

Hawkeye Creek. Cladophora dominated the sample from Hawkeye Creek (Table 3). Vaucheria was frequent and ranked second in biovolume, while diatoms were also frequent and ranked third. Two other genera of green algae completed the periphyton community at this site.

Warm Springs Creek. The macrophytic green alga Chara dominated the sample from this site (Table 3). Dominance by this alga indicates a stream with hard waters, gentle gradient, slow current velocity, and a muddy bottom. The nitrogen-fixing cyanophyte Nostoc was also abundant here, indicating that nitrogen may be the limiting nutrient at this site. A total of 8 genera of green and blue-green algae comprised the non-algal flora here.

Mill Gulch. Diatoms and an occasional cell of the desmid Closterium were the only algae found in the sample from Mill Creek (Table 3).

Garden Creek. The upper and lower sites on Garden Creek had very similar algal floras (Table 3). Diatoms ranked first in biovolume at both sites, followed by the cyanophyte 
Oscillatoria. Amphithrix, a cyanophyte that prefers cool waters, was common at the upper site but absent from the lower site.

Mormon Creek. An occasional diatom and filament of Cladophora were the only algae found in the sample from Mormon Creek (Table 3).

North Fork Greenhorn Creek. Diatoms ranked first in biovolume, followed by three genera of green algae and the red alga Audouinella, which indicates cool water temperatures.

West Fork Ruby River. Besides diatoms, which were abundant and ranked first in biovolume, this site supported 7 genera of algae, including green algae, blue-green algae, and the red alga Audouinella (Table 3).

\section{Diatoms}

All of the major diatom species from the Ruby River TMDL planning area are included in pollution tolerance classes 3 and 2, and are either sensitive to organic pollution or only somewhat tolerant of organic pollution (Table 4). None of the major diatom species are most tolerant of organic pollution (pollution tolerance class $=1$ ).

Stresses indicated at some of the sites appear to be natural in origin. For example, high values for the disturbance index and percent dominant species in upper Ramshorn Creek and Shovel Creek indicate moderate stress related to steep gradients, fast currents, cold temperatures, and low nutrient concentrations. High values for the pollution index and low values for the siltation index and percent abnormal cells indicate that organic enrichment, sedimentation, and toxic metals did not have a significant effect on the benthic algae at these sites (Table 4). Lower but still elevated values for the disturbance index and percent dominant species indicate minor natural stress in Currant Creek, upper California Creek, Harris Creek, and upper Garden Creek.

Coal Creek. The dominant diatom species in upper Coal Creek was Epithemia sorex (Table 4). Cells of this diatom harbor nitrogen-fixing blue-green algae as endosymbionts. Along 
with the several genera of free-living nitrogen-fixing blue-green algae found at this site, the large number of Epithemia sorex indicates that nitrogen is likely the limiting nutrient in upper Coal Creek. Aside from a slightly depressed diversity index (due to dominance by E. sorex), there was no other indication of natural or anthropogenic stress or impairment in upper Coal Creek. At the lower site on Coal Creek, a depressed pollution index and an elevated siltation index indicated minor impairment from organic loading and sedimentation in July. In September, a very large number of Diatoma moniliformis indicated elevated dissolved solids in lower Coal Creek, possibly due to diminished stream flow. A depressed pollution index also indicated minor impairment from organic loading in September. The depressed diversity index was due mostly to the very large number of $D$. moniliformis that were present at this time. The upper and lower sites on Coal Creek shared less than 20 percent of their diatom assemblages in September, indicating that a major change in environmental conditions occurred between them.

Indian Creek. The upper site on Indian Creek had a slightly depressed pollution index that indicated minor impairment from organic loading. This site supported large numbers of Fragilaria vaucheriae and Synedra ulna, both of which tolerate small amounts of organic matter. Hannaea arcus, an indicator of clean, cold waters, was also a major species here. Other than slight organic loading at the upper site, diaton metrics indicated excellent biological integrity, no impairment, and full support of aquatic life uses at both sites (Table 4).

Ramshorn Creek. Aside from the natural stress evident in upper Ramshorn Creek, this site had excellent biological integrity and no impairment (Table 4). An elevated siltation index and a depressed pollution index indicate moderate impairment from sedimentation and minor impairment from organic loading in lower Ramshom Creek. The lower site shared only 17 percent of its diatom assemblage with the upper site, indicating that major environmental changes occurred between the two sites.

Currant Creek. In addition to the natural stress evident in Currant Creek, this site exhibited minor impairment from sedimentation (Table 4). Other metrics indicated no impairment and excellent biological integrity. 
California Creek. The upper site on California Creek supported a few teratological diatom cells and the lower site supported a few more abnormal cells, indicating possible minor impairment from heavy metals at both sites (Table 4). The lower site supported an exceptionally large number of motile diatoms for a mountain stream, which indicated severe impairment from sedimentation. A slightly depressed pollution index suggests minor impairment from organic loading at the lower site. The two sites shared only 18 percent of their diatom floras, indicating that a major change in environmental conditions occurred between these sites.

Harris Creek. Borderline values for the pollution index and siltation index suggest minor impairment from organic loading and sedimentation in Harris Creek. A somewhat elevated percentage of Achnanthidium minutissimum suggests minor stress from natural environmental conditions (Table 4).

Shovel Creek. Aside from a large number of Achnanthidium minutissimum and natural stress due to steep gradients, coldwater temperatures and low nutrients, diatom metrics indicate good biological integrity in Shovel Creek. One abnormal diatom valve was counted at this site.

Hawkeye Creek. Hawkeye Creek supported an exceptionally large number of motile diatoms for a mountain stream, suggesting severe impairment from sedimentation (Table 4). This site also had a slightly depressed pollution index, indicating minor impairment from organic loading. A single teratological diatom valve was counted at this site.

Warm Springs Creek. An elevated number of motile diatoms here indicate minor impairment from sedimentation (Table 4). One teratological diatom valve was counted at this site. Otherwise, diatom metrics indicated excellent biological integrity in Warm Springs Creek.

Mill Gulch. Other than a single abnormal diatom valve and a slightly elevated siltation index, Mill Gulch had excellent biological integrity for a mountain stream (Table 4). Diatom species richness in Mill Gulch was exceptional (70 species counted). 
Garden Creek. Aside from minor natural stress and a single abnormal diatom valve, the upper site on Garden Creek had excellent biological integrity (Table 4). The lower site on Garden Creek supported an elevated number of motile diatoms for a mountain stream, indicating minor impairment from sedimentation. A few teratological diatom valves were also counted at this site. The two sites on Garden Creek shared over 40 percent of their diatom assemblages, which indicates that only minor environmental change occurred between them.

Mormon Creek. An elevated number of motile diatoms indicate moderate impairment from sedimentation in Mormon Creek. A depressed pollution index also indicates minor impairment from organic loading. A relatively large number of teratological diatoms suggests that this site may have elevated concentrations of heavy metals.

North Fork Greenhorn Creek. Over 13 percent of the diatoms at this site were abnormal (Table 4), which suggests severe impairment from heavy metals. The number of motile diatoms here was also elevated, indicating minor impairment from sedimentation. The pollution index was near the threshold for minor impairment and the dominant species here (Synedra ulna) is tolerant of organic loading $(\mathrm{PTC}=2)$.

West Fork Ruby River. A large number of motile diatoms indicate moderate impairment from sedimentation at this site. The pollution index was also depressed, indicating minor impairment from organic loading. No teratological diatom cells were counted at this site.

\section{Modal Categories}

Several ecological attributes assigned by Stevenson and Van Dam et al. (1994) were selected from the diatom reports in the appendix and modal categories of these attributes were extracted to characterize water quality tendencies in streams of the Ruby River TMDL planning area (Table 5). The largest category of diatoms at most sites was "not motile", but highly motile diatoms comprised the largest category in California Creek near mouth, Hawkeye Creek, and the West Fork of the Ruby River. These three sites also had the highest sedimentation indexes. 
The modal category for $\mathrm{pH}$ at all of the sites was either circumneutral or alkaliphilous, except at the upper site on Coal Creek, where the nodal category was alkalibiontic. While alkaliphilous diatoms prefer $\mathrm{pH}$ values greater than 7 , alkalibiontic diatoms require $\mathrm{pH}$ values greater than 7. The higher $\mathrm{pH}$ in upper Coal Creek may have been transient and due, in part, to a large standing crop of algae undergoing photosynthesis. All of the sites were rated as freshbrackish ( $<900 \mathrm{mg} / \mathrm{L}$ dissolved solids) except the lower site on Coal Creek in September, where the modal category was brackish-fresh (900-1800 mg/L dissolved solids). Elevated dissolved solids at this site were also indicated by a large number of salt-tolerant diatoms in the species Diatoma moniliformis (Table 5).

The modal category for nitrogen uptake at most of the sites was of nitrogen autotrophic taxa that tolerate elevated concentrations of organically bound nitrogen (Van Dam et al. 1994). At the upper site on Coal Creek the modal category was also of nitrogen autotrophs, but those that tolerate only very small concentrations of organically bound nitrogen (Table 5). Most sites had fairly high or continuously high requirements for dissolved oxygen, but the modal category at four sites was only moderate: Coal Creek at mouth (September), upper Indian Creek, Mormon Creek, and North Fork Greenhorn Creek. A "moderate" rating is equivalent to $50 \%$ saturation by dissolved oxygen, whereas fairly high and continuously high ratings are equivalent to $75 \%$ and 100\% saturation, respectively (Van Dam et al. 1994).

Beta-mesosaprobous was the modal category for saprobity at most sites. This indicates water that is relatively free of organic matter, oxygen saturation levels ranging from $70-85 \%$, and BOD concentrations ranging from 2-4 milligrams per liter (Van Dam et al. 1994). The modal category at two sites was alpha-mesosaprobous, which indicates elevated organic matter, 25-70\% oxygen saturation, and BOD concentrations ranging from 4-13 mg/L. These two sites--lower Coal Creek (September) and lower Ramshorn Creek-also had the lowest pollution index values (Table 4).

Except for two sites where the modal category for trophic status was "not classified", all of the sites supported mostly eutraphentic diatoms or diatoms that tolerate a wide range of 
trophic conditions from oligotrophic to hypereutrophic (Van Dam et al. 1994). Eutraphentic diatoms require large concentrations of macronutrients (N, P, and $\mathrm{C}$ ) for optimum growth.

\section{References}

APHA. 1998. Standard Methods for the Examination of Water and Wastewater. 20 ${ }^{\text {th }}$ Edition. American Public Health Association, Washington, D.C.

Bahls, L.L. 1979. Benthic diatom diversity as a measure of water quality. Proceedings of the Montana Academy of Sciences 38:1-6.

Bahls. L.L. 1993. Periphyton Bioassessment Methods for Montana Streams (revised). Montana Department of Health and Environmental Sciences, Helena.

Bahls, L.L., Bob Bukantis, and Steve Tralles. 1992. Benchmark Biology of Montana Reference Streams. Mlontana Department of Health and Environmental Sciences, Helena.

Barbour, M.T., J. Gerritsen, B.D. Snyder, and J.B. Stribling. 1999. Rapid Bioassessment Protocols for Use In Streams and Wadeable Rivers: Periphyton, Benthic Macroinvertebrates and Fish. Second Edition. EPA 841-B-99-002. U.S. Environmental Protection Agency, Office of Water, Washington, D.C.

Beaver, Janet. 1981. Apparent Ecological Characteristics of Some Common Freshwater Diatoms. Ontario Ministry of The Environment, Technical Support Section, Don Mills, Ontario.

Johansen, J.R. 1999. Diatoms of Aerial Habitats. Chapter 12 in Stoermer, E.F., and J.P. Smol (eds.), The Diatoms: Applications For the Environmental and Earth Sciences, Cambridge University Press, New York.

John, D.M., B.A. Whitton, and A.J. Brook (eds.). 2002. The Freshwater Algal Flora of the British Isles: An Identification Guide to Freshwater and Terrestrial Algae. Cambridge University

Karr, J.R., and D.R. Dudley. 1981. Ecological perspectives on water quality goals. Environmental Management 5:55-69.

Krammer, Kurt. 1997a. Die cymbelloiden Diatomeen: Eine Monographie der weltweit bekannten Taxa. Teil 1. Allgemeines and Encyonema Part. J. Cramer, Berlin.

Krammer, Kurt. 1997b. Die cymbelloiden Diatomeen: Eine Monographie der weltweit bekannten Taxa. Teil 2. Encyonema part. Encyonopsis and Cymbellopsis. J. Cramer, Berlin.

Krammer, Kurt. 2002. Cymbella. Volume 3 in Diatoms of Europe, Horst Lange-Bertalot, ed. A.R.G. Gantner Verlag K.G., Germany.

Krammer, K, and H. Lange-Bertalot. 1986. Bacillarıphyceae, Part 2, Volume 1: Naviculaceae. In Ettl, H., J Gerloff, H. Heynig, and D. Mollenhauer (eds.), Freshwater Flora of Middle Europe. Gustav Fischer Publisher, New York. 
Krammer, K., and H. Lange-Bertalot. 1988. Bacillariophyceae, Part 2, Volume 2: Bacillariaceae, Epithemiaceae, Surirellaceae. In Ettl, H., J. Gerloff, H. Heynig, and D. Mollenhauer (eds.), Freshwater Flora of Middle Europe. Gustav Fischer Publisher, New York.

Krammer, K., and H. Lange-Bertalot. 1991a. Bacillariophyceae, Part 2, Volume 3: Centrales, Fragilariaceae, Eunotiaceae. In Ettl, H., J. Gerloff, H. Heynig, and D. Mollenhauer (eds.), Freshwater Flora of Middle Europe. Gustav Fischer Publisher, Stuttgart.

Krammer, K., and H. Lange-Bertalot. 1991b. Bacillariophyceae, Part 2, Volume 4: Achnanthaceae, Critical Supplement to Navicula (Lineolatae) and Gomphonema, Complete List of Literature for Volumes 1-4. In Ettl, H., G. Gartner, J. Gerloff, H. Heynig, and D. Mollenhauer (eds.), Freshwater Flora of Middle Europe. Gustav Fischer Publisher, Stuttgart.

Lange-Bertalot, Horst. 1979. Pollution tolerance of diatoms as a criterion for water quality estimation. Nova Hedwigia 64:285-304.

Lange-Bertalot, Horst. 1993.85 new taxa and much more than 100 taxonomic clarifications supplementary to Susswasserflora von Mitteleuropa Vol. 2/I-4. J. Cramer, Berlin.

Lange-Bertalot, Horst. 1996. Rote Liste der limnischen Kieselalgen (Bacillariophyceae) Deutschlands. Schr.-R. f. Vegetationskde., H. 28, pp. 633-677. BfN, Bonn-Bad Godesberg.

Lange-Bertalot, Horst. 2001. Navicula sensu stricto: 10 Genera Separated from Navicula sensu lato; Frustulia. Volume 2 in Diatoms of Europe, Horst Lange-Bertalot, ed. A.R.G. Gantner Verlag K.G., Germany.

Lowe, R.L. 1974. Environmental Requirements and Pollution Tolerance of Freshwater Diatoms. EPA-670/4-74-005. U.S. Environmental Protection Agency, National Environmental Research Center, Office of Research and Development, Cincinnati, Ohio.

McFarland, B.H., B.H. Hill, and W.T. Willingham. 1997. Abnormal Fragilaria spp. (Bacillariophyceae) In streams impacted by nine drainage. Journal of Freshwater Ecology 12(1):141-149.

Morales, E.A., and Marina Potapora. 2000. Third NAWQA Workshop on Harmonization of Algal Taxonomy, May 2000. Patrick Center for Environmental Research, The Academy of Natural Sciences, Philadelphia.

Palmer, C.M. 1969. A composite rating of algae tolerating organic pollution. Joumal of Phycology 5:78-82.

Palmer, C.M. 1977. Algae and Water Pollution: An Illustrated Mlanual on the Identification, Significance, and Control of Algae in Water Supplies and in Polluted Water. EPA-600/9-77-036.

Plafkin, J.L., M.T. Barbour, K.D. Porter, S.K. Gross, and R.M. Hughes. 1989. Rapid Bioassessment Protocols for Use in Rivers and Streams: Benthic Macroinvertebrates and Fish. EPA 440-4-89-001.

Prescott, G.W. 1962. Algae of the Western Great Lakes Area. Wm. C. Brown Company, Dubuque, Iowa.

Prescott, G.W. 1978. How to Know the Freshwater Algae. Third Edition. Wm. C. Brown Company Publishers, Dubuque, lowa.

Reichardt, Erwin. 1997. Taxonomische Revision des Artenkomplexes um Gomphonema pumilum (Bacillariophyta). Nova Hedwigia 65(1-4):99-129.

Reichardt, Erwin. 1999. Zur Revision der Gattung Gomphonema. A.R.G. Gantner Verlag, Distributed by Koeltz Scientific Books, Konigstein, Germany.

Renfro, H.B., and D.E. Feray. 1972. Geological Highway Map of the Northern Rocky Mountain Region. American Association of Petroleum Geologists, Tulsa, Oklahoma. 
Smith, G.M. 1950. The Fresh-Water Algae of The United States. McGraw-Hill Book Company, New York.

Stevenson, R.J., and Y. Pan. 1999. Assessing Environmental Conditions in Rivers and Streams with Diatoms. Chapter 2 in Stoermer, E.F., and J.P. Smol (eds.), The Diatoms: Applications For the Environmental and Earth Sciences, Cambridge University Press, New York.

Stewart. W.D.P., P. Rowell, and A.N. Rai. 1980. Symbiotic Nitrogen-Fixing Cyanobacteria. Pp. 239-277 in Stewart, W.D.P., and J. Gallo (eds.), Nitrogen Fixation, Academic Press, New York.

USDA. 1976. Climax Vegetation of Montana (map). U.S. Department of Agriculture, Soil Conservation Service, Cartographic Unit, Portland.

USEPA. 2000. Level 111 Ecoregions of the Continental United States (map). National Health and Environmental Effects Research Laboratory, U.S. Environmental Protection Agency, Corvallis, Oregon.

Van Dam, Herman, Adrienne Mertens, and Jos Sinkeldam. 1994. A coded checklist and ecological Indicator valies of freshwater diatoms from The Netherlands. Netherlands Journal of Aquatic Ecology 28(1):117-133.

Weber, C.1. (ed.). 1973. Biological Field and Laboratory Methods for Measuring the Quality of Surface Waters and Effluents. EPA-670/4-73-001. U.S. Environmental Protection Agency, National Environmental Research Center, Office of Research and Development, Cincinnati, Ohio.

Wehr, J.D., and R.G. Sheath. 2003. Freshwater Algae of North America: Ecology and Classification. Academic Press, New York.

Whittaker, R.H. 1952. A study of summer folage insect communities in the Great Snoky Mountains. Ecological Monographs 22:1-44.

Woods, A.J., Omernik, J.M., Nesser, J.A., Shelden, J., and S.H. Azevedo. 1999. Ecoregions of Montana (color poster with map), U.S. Geological Survey, Reston, Virginia. 


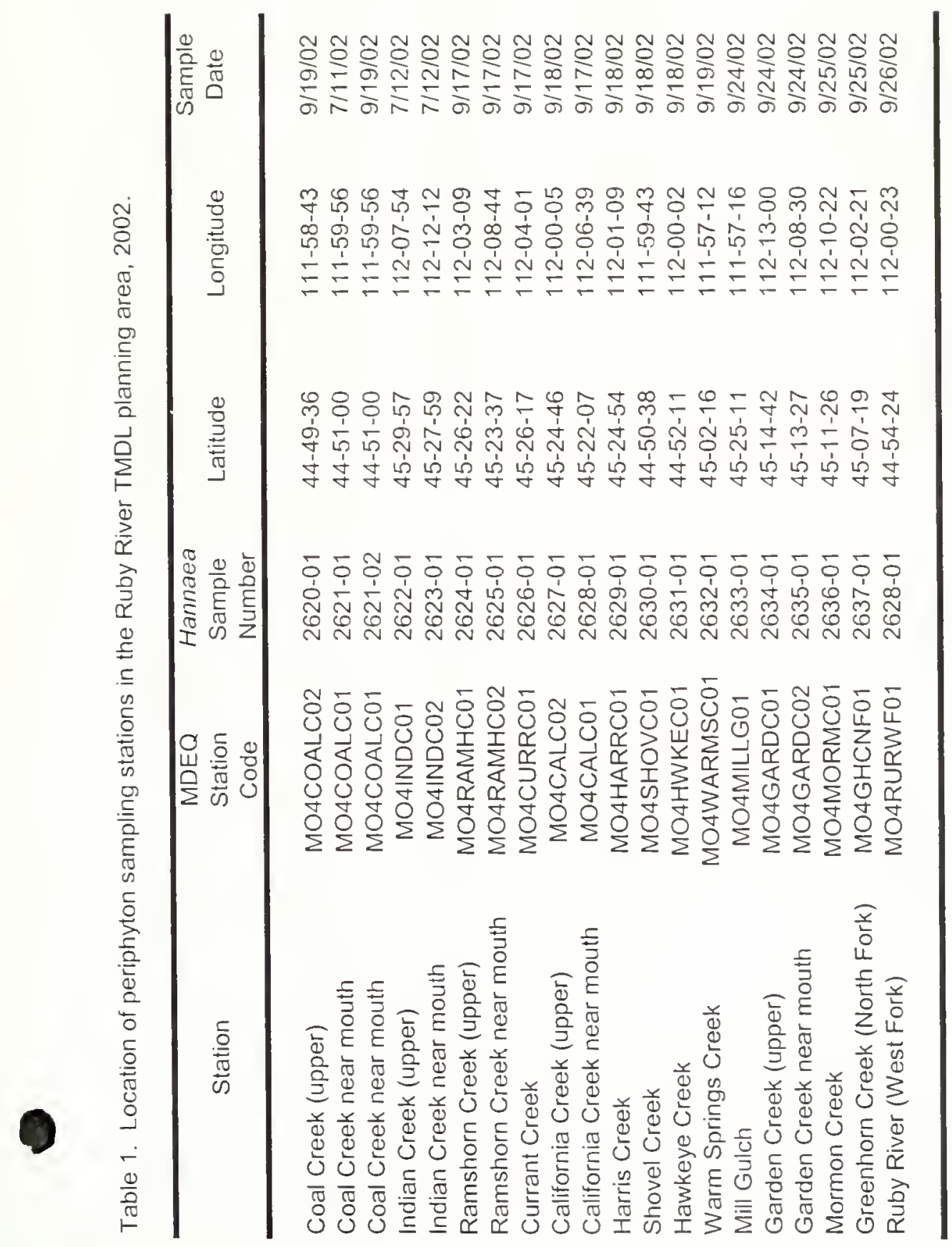




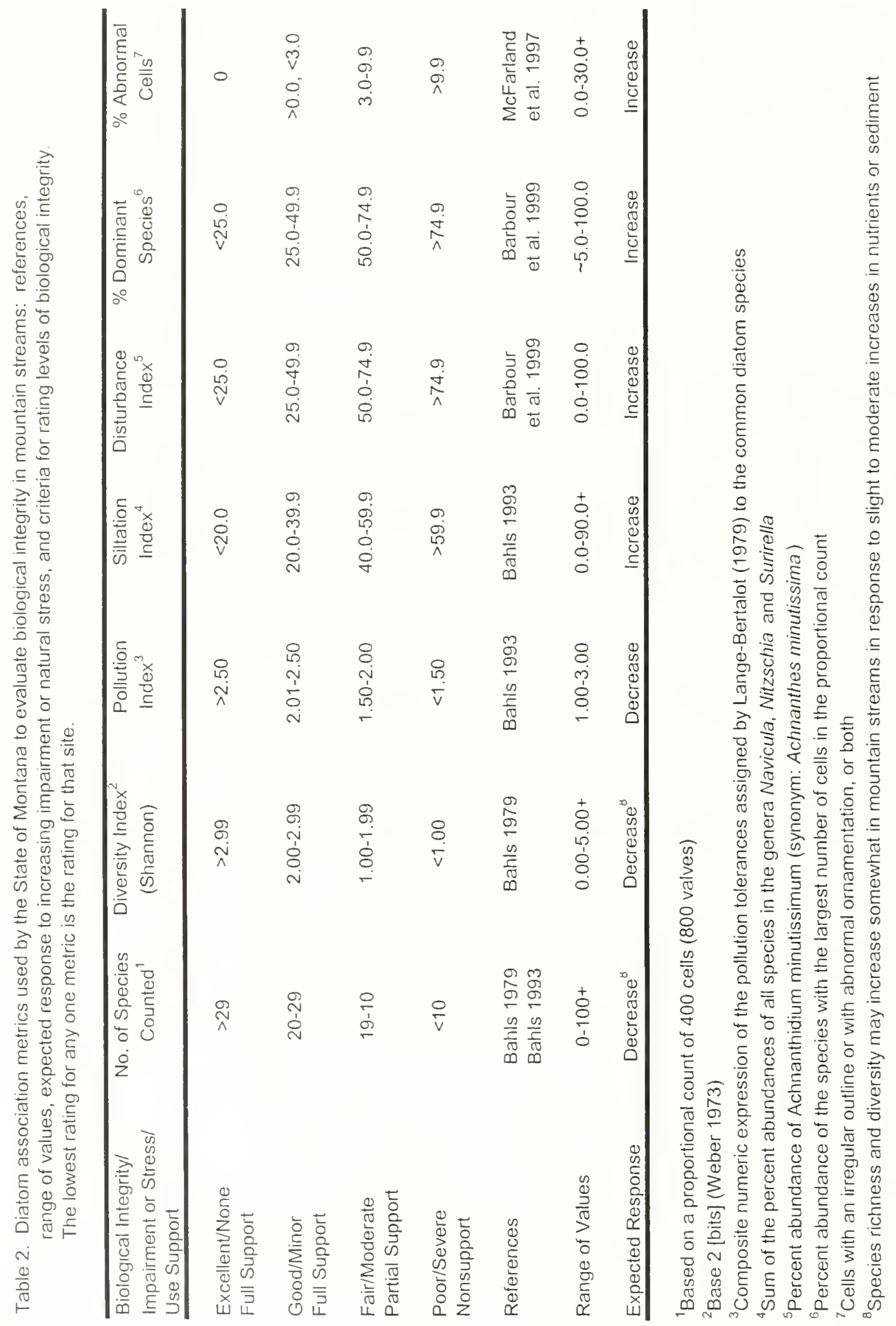




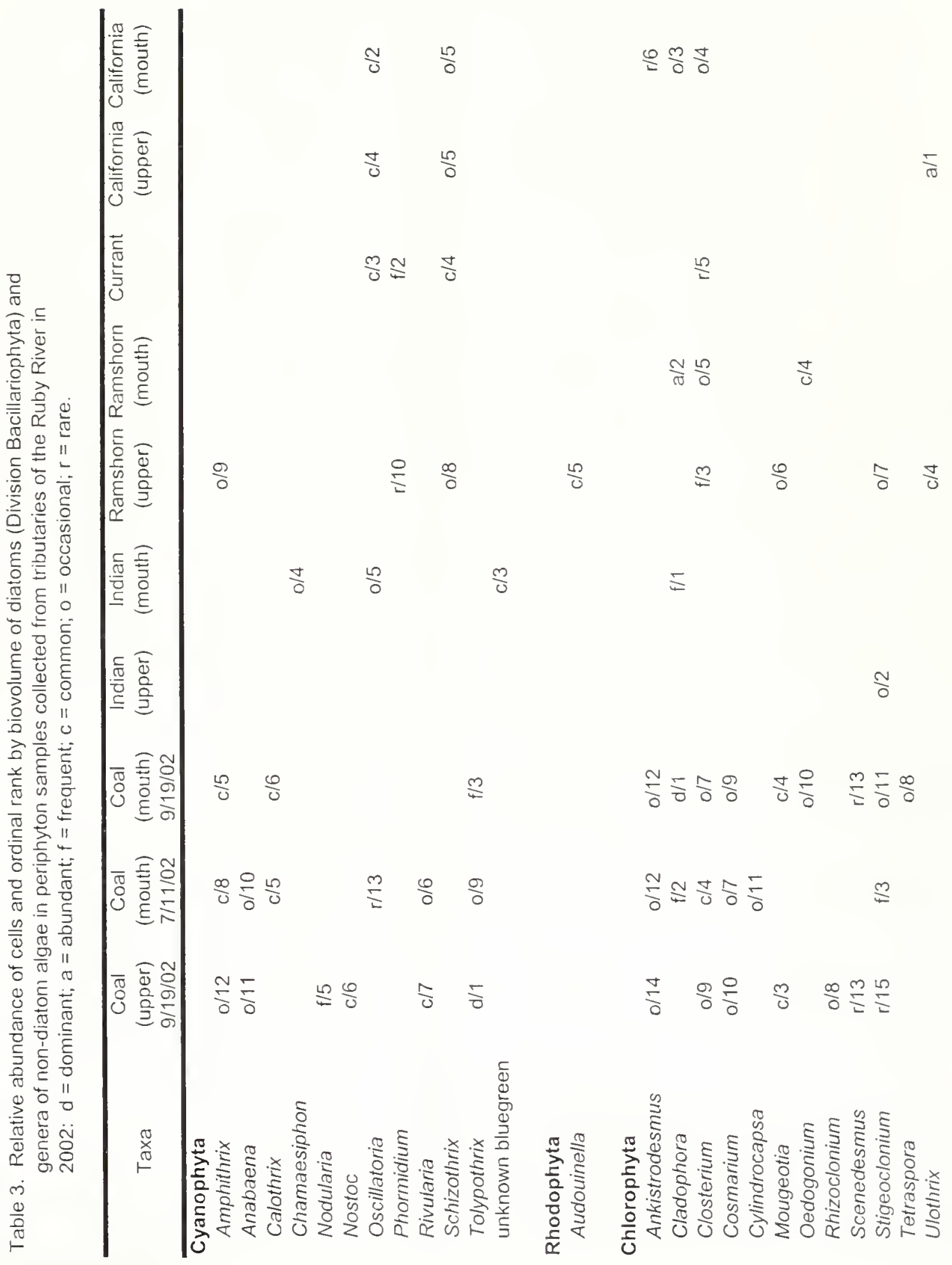




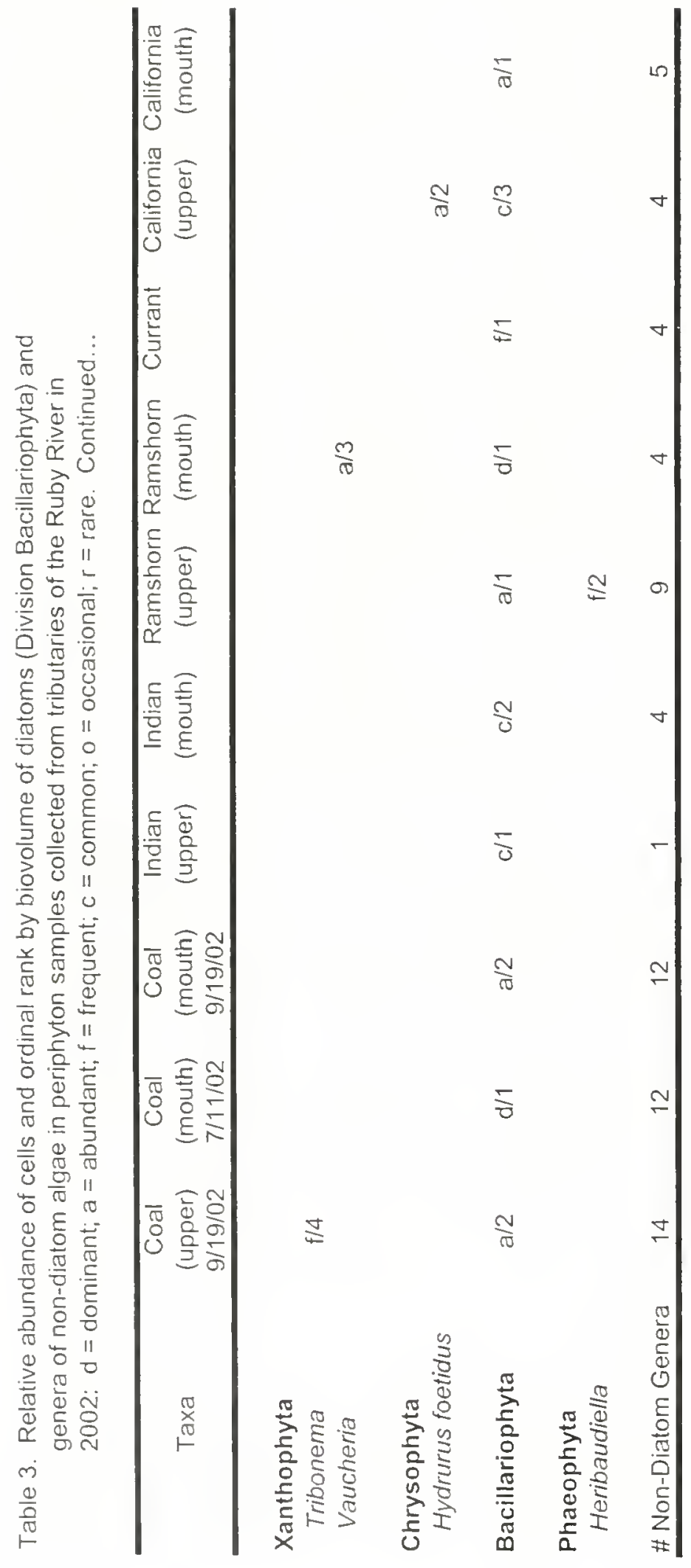









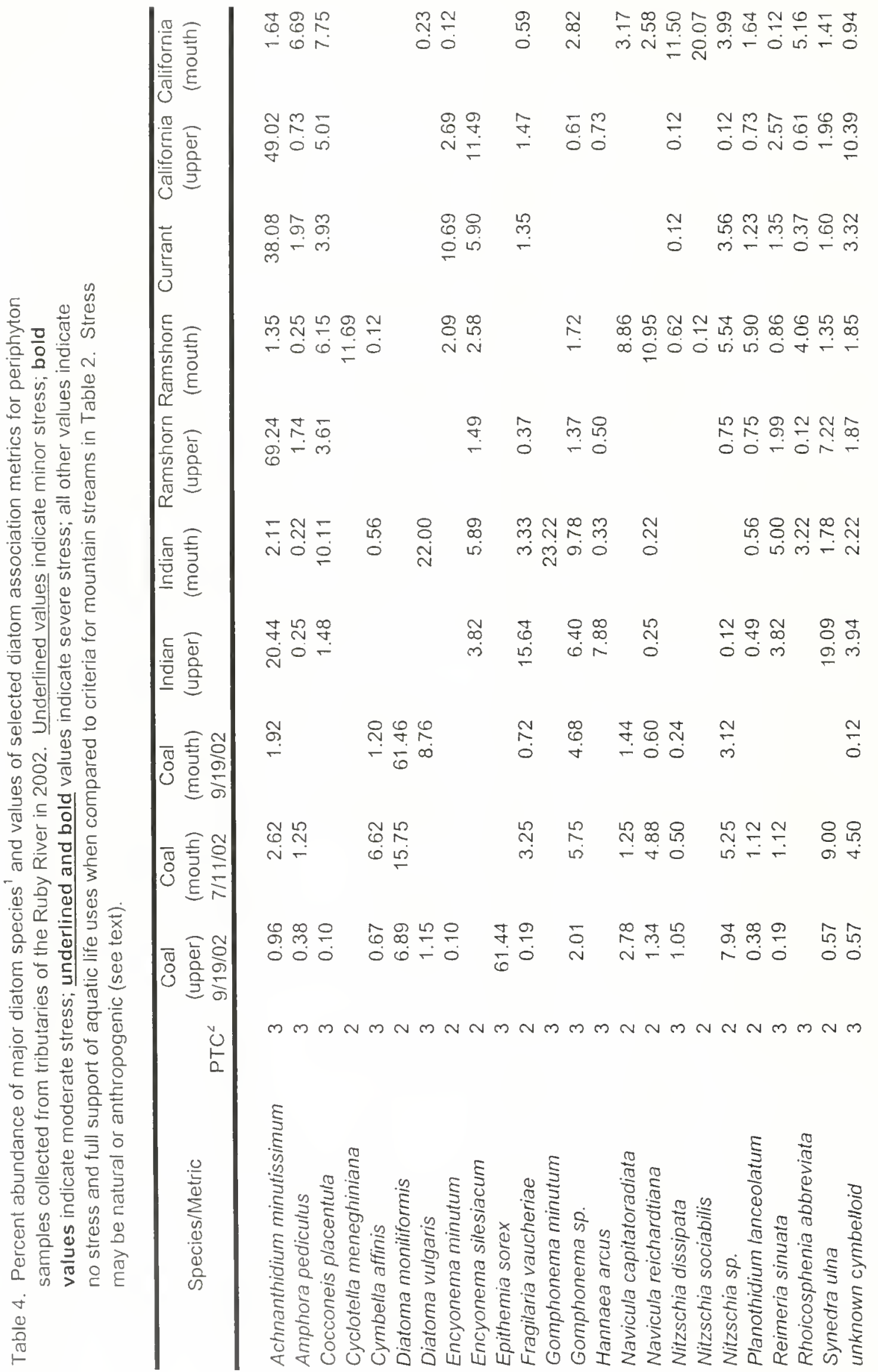




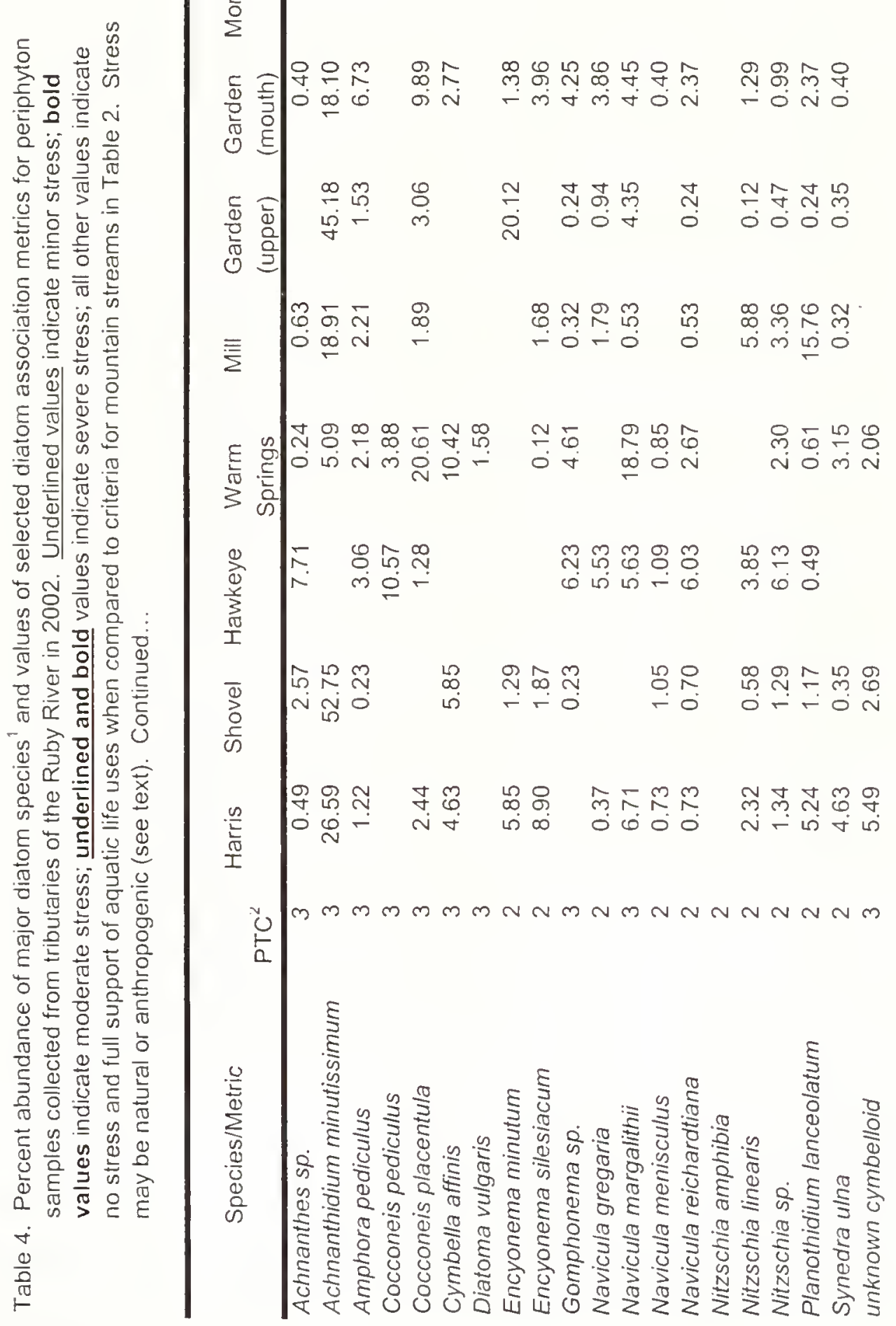









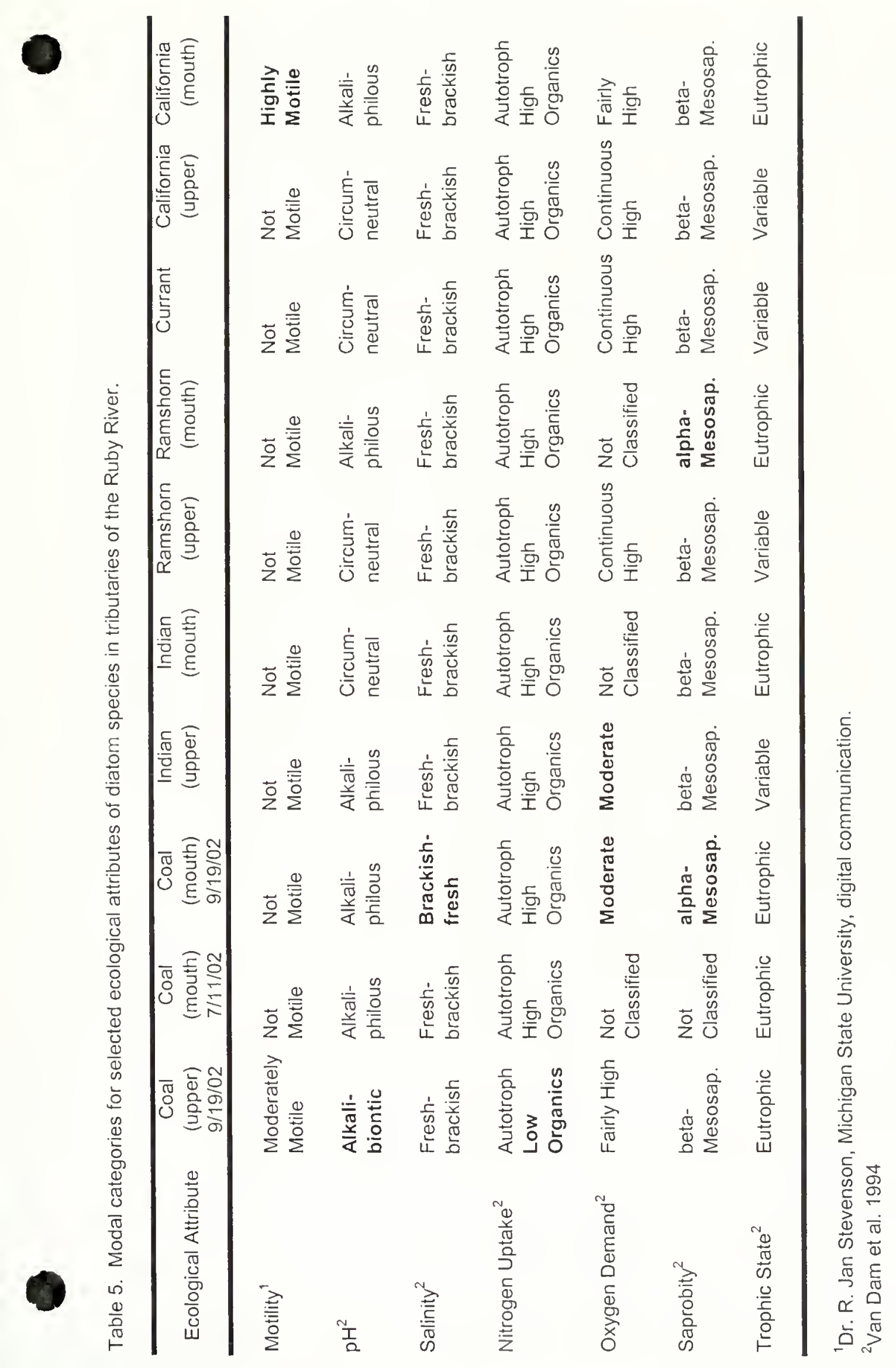




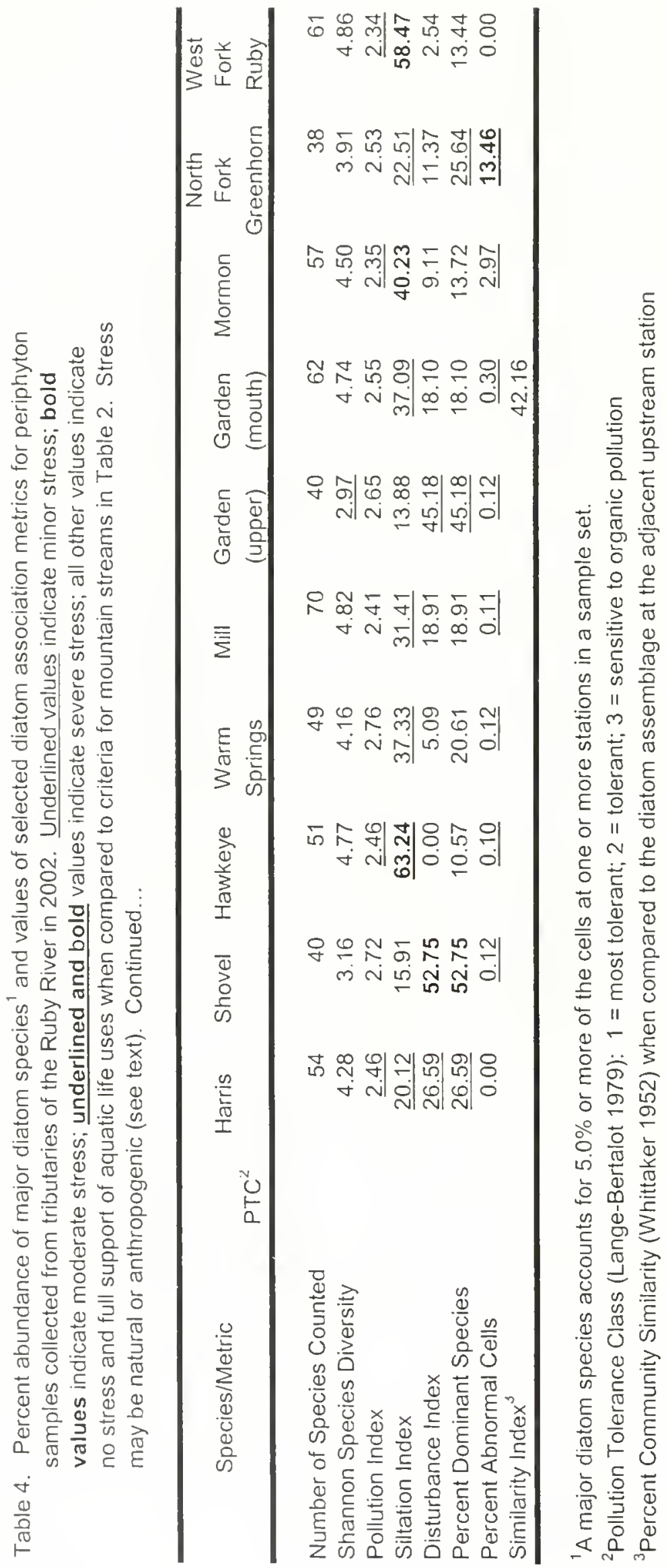




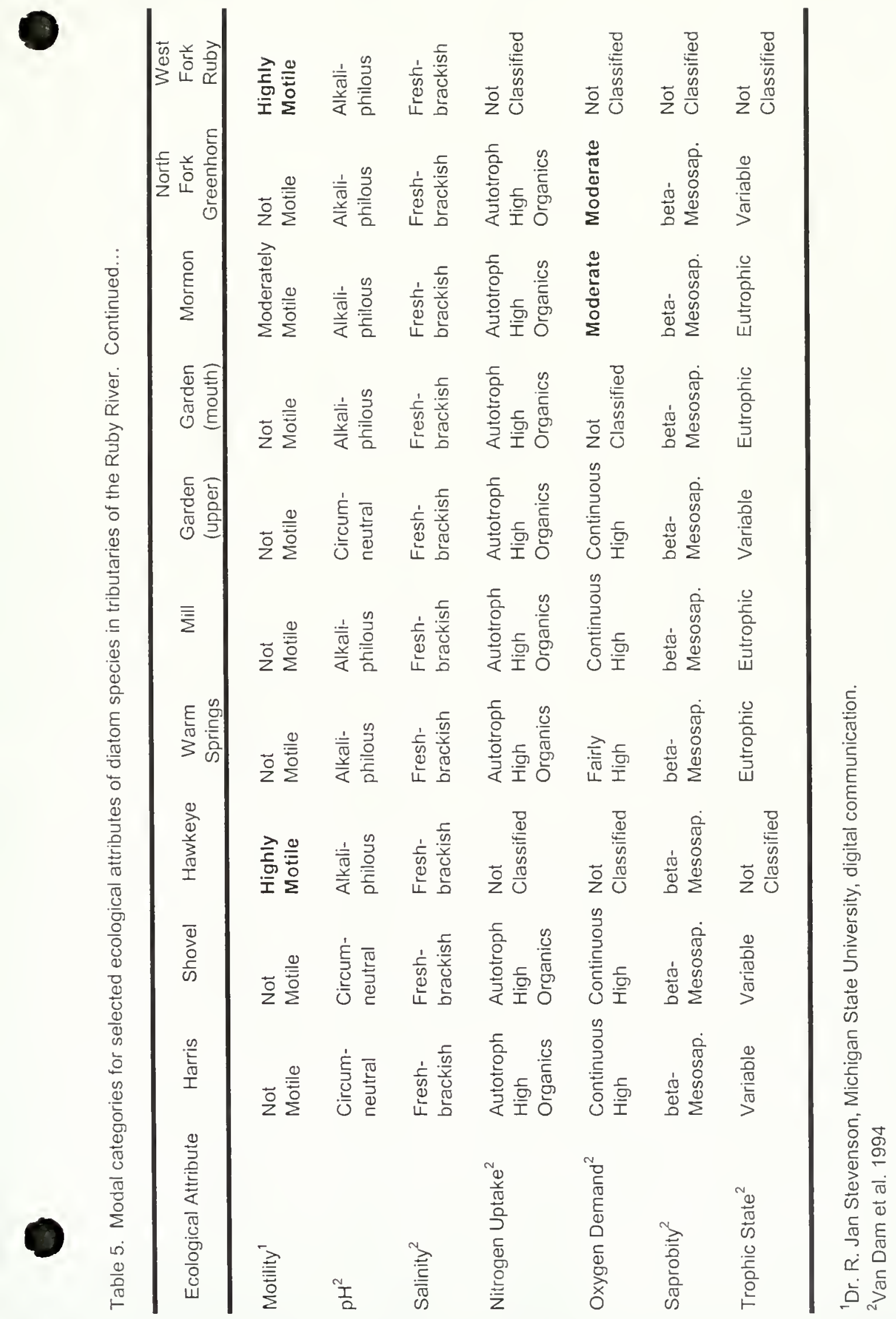




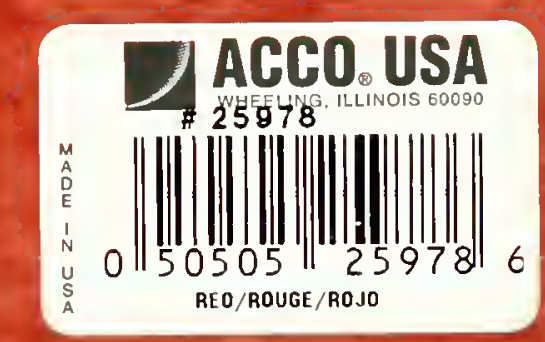




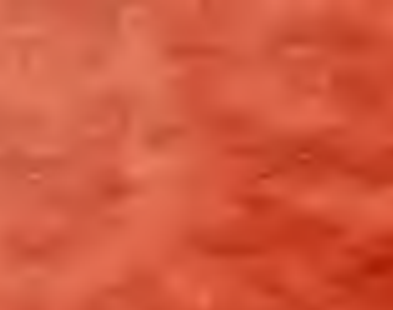

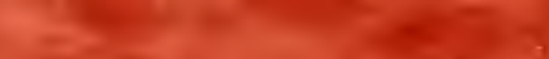

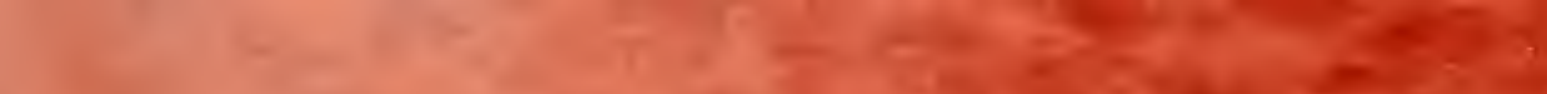

